\title{
Deskripsi, Metabolit Sekunder dan Kegunaan Anyang-Anyang \\ (Elaeocarpus grandiflorus J.E. Smith)
}

\author{
Danner Sagala \\ Universitas Prof. Dr. Hazairin, SH \\ J1. Jend. Sudirman No. 185 Bengkulu, Indonesia \\ Email: danner_10@unihaz.ac.id
}

\begin{abstract}
Abstrak
Anyang-anyang merupakan tumbuhan liar dan banyak ditemukan di alam. Tanaman ini dapat digunakan sebagai tanaman obat karena mengandung metabolit sekunder yang berfungsi dalam membantu penyembuhan beberapa penyakit. Kandungan metabolit sekunder yang telah berhasil diisolasi terdiri dari kelompok fenolik, terpenoid dan alkaloid.
\end{abstract}

Kata kunci: Anyang-anyang, Elaeocarpus grandiflorus J.E. Smith, fenolik, terpenoid

\section{PENDAHULUAN}

Makhluk hidup mempunyai kemampuan yang bervariatif dalam melakukan sintesis dan transformasi senyawa organik dalam tubuhnya. Misalnya tanaman sangat efektif menggunakan proses fotosintesis untuk sintesis karbohidrat; sedangkan organisme lain seperti mikroba dan hewan melakukan sintesis dari senyawa anorganik yang dikonsumsinya. Jadi jalur-jalur metabolik secara garis besar dapat di bagi ke dalam dua macam jalur, yaitu jalur yang bertanggung jawab terhadap degradasi material yang dikonsumsi, dan jalur yang bertanggung jawab terhadap sintesis senyawa-senyawa organik tertentu (yang dibutuhkan) dari senyawa dasar yang didapatnya. Meskipun karakteristik makhluk hidup sangatlah bervariasi, akan tetapi jalur metabolik yang secara umum mensintesis dan memodifikasi senyawa-senyawa karbohidrat, protein, lemak dan asam nukleat ternyata secara esensial sama pada semua makhluk (bersifat universal); walaupun ada sedikit penyimpangan. Kesamaan ini menunjukkan adanya keseragaman proses yang fundamental pada semua mahluk hidup, yang secara kolektif disebut sebagai metabolisme primer, dan segala senyawa yang terlibat didalam jalur metabolisme tersebut disebut sebagai metabolit primer (Rahmawati, 2014).

Berlawanan dengan jalur metabolisme primer terdapat jalur metabolisme lain yang melibatkan senyawa-senyawa organik spesifik dan terjadi sangat terbatas di alam. Metabolisme itu disebut metabolisme sekunder, dan senyawa yang dihasilkan disebut sebagai metabolit sekunder. Metabolit sekunder tertentu hanya ditemukan pada organisme spesifik, atau bahkan 
strain (galur) yang spesifik, dan hanya diproduksi pada kondisi-kondisi tertentu (Rahmawati, 2014).

Salah satu dari organisme spesifik yang menghasilkan metabolit sekunder tersebut adalah anyang-anyang. Anyang-anyang sudah lama diketahui sebagai tanaman berkhasiat obat oleh masyarakat Indonesia, misalnya kulit kayunya digunakan untuk mengobati radang ginjal dan obat luka luar. Sejauh ini tumbuhan ini dikenal dan dimanfaatkan karena khasiat obat yang terkandung di metabolit sekundernya, belum diketahui khasiat lain dari metabolit sekunder tersebut misalnya sebagai alat pertahanan atau atraktan bagi serangga.

Paper ini akan memberi deskripsi mengenai klasifikasi botanis tumbuhan anyanganyang, kandungan senyawa metabolit sekunder, lintasan metabolit sekunder dan kegunaannya.

\section{KLASIFIKASI DAN DESKRIPSI ANYANG-ANYANG}

Nama ilmiah tumbuhan anyang-anyang adalah Elaeocarpus grandiflorus J.E.Smith. Tumbuhan ini termasuk ke dalam keluarga Tiliaceae. Klasifikasi botanis secara lengkap menurut Sekolah Ilmu dan Teknologi Hayati Institut Teknologi Bandung (2014) adalah:

Divisi : Magnoliophyta

Kelas : Magnoliopsida

Bangsa : Malvales

Suku : Tiliaceae

Marga : Elaeocarpus

Jenis : Elaeocarpus grandiflorus J.E.Smith

Di Indonesia, tanaman ini dikenal dengan berbagai nama daerah yaitu kayu anyang, ki ambit (sunda), kematian atau raja sor, rejasa (jawa). Penamaan simplisia anyang-anyang tergantung dari bagian tanaman yang digunakan karena hamper seluruh bagian tanaman anyang-anyang telah digunakan sebagai obat seperti daun (folium), kulit kayu (cortex), buah (fruktus) dan biji (semen).

Menurut Informasi di dalam ASEAN Tropical Data Base (2014), tumbuhan anyanganyang merupakan pohon yang hijau sepanjang tahun dan dapat tumbuh hingga mencapai 25 m. Anyang-anyang memiliki daun lanset, muncul dan tumbuh berkumpul di ujung ranting. Ukuran daun berkisar 4,5-20 cm x 1,2-5 cm dengan panjang tangkai daun 0,2-4 cm.

Bunga terbentuk segugusan di antara daun, terjumbai dengan panjang 2-10 cm. Satu gugus bunga berjumlah 4-6 bunga dengan panjang tangkai bunga 2,5 $\mathrm{cm}$. Sepal berbentuk lanset dengan panjang 1,2-2,5 $\mathrm{cm}$ x 0,2 cm berwarna merah cerah. Petal berukuran 2-2,5 $\mathrm{cm} \mathrm{x}$ Cara menyitat: Sagala, Danner, 2018. "Deskripsi, Metabolit Sekunder Dan Kegunaan Anyang-anyang (elaeocarpus Grandiflorus J.E. Smith)". INA-Rxiv. February 10. osf.io/preprints/inarxiv/3unv8 
$1 \mathrm{~cm}$ berwarna murni putih. Di dalam petal terdapat benang sari yang berjumlah 25-60, panjang filamen 2-4 mm dan panjang kepala sari 2,5-6 mm. Buah berbiji ellipsoid dengan ukuran 2,5$4 \mathrm{~cm} \times 1,5-2 \mathrm{~cm}$, berwarna hijau pucat. Biji ditutupi dengan duri/spine yang bengkok (Gambar $1)$.

Anyang-anyang tersebar di Myanmar dan Indo-China ke Thailand, Semenanjung Malaysia, Singapura, dan Filipina. Di Indonesia, anyang-anyang banyak terdapat di Sumatera, Jawa, Bali, dan Kalimantan

Penggunaan anyang-anyang telah lama dikenal sebagai obat terutama di daerah Jawa. Di Jawa Timur, kulit dihancurkan dan digunakan untuk radang usus akut (poulticing ulkus persisten). Di Jawa Barat, kulit merupakan bahan obat tradisional untuk penyakit perempuan. Di Jawa Tengah, rebusan daun diminum sebagai tonik umum dan digunakan untuk penderita sakit empedu. Daun merupakan bahan dari obat tradisional terhadap sifilis. Biji merupakan bahan umum pada banyak jamu tradisional. Anyang-anyang ini diperhitungkan memiliki sifat diuretik ringan dan dimasukkan dalam resep untuk meringankan batu kandung kemih dan buang air kecil sakit pada umumnya.
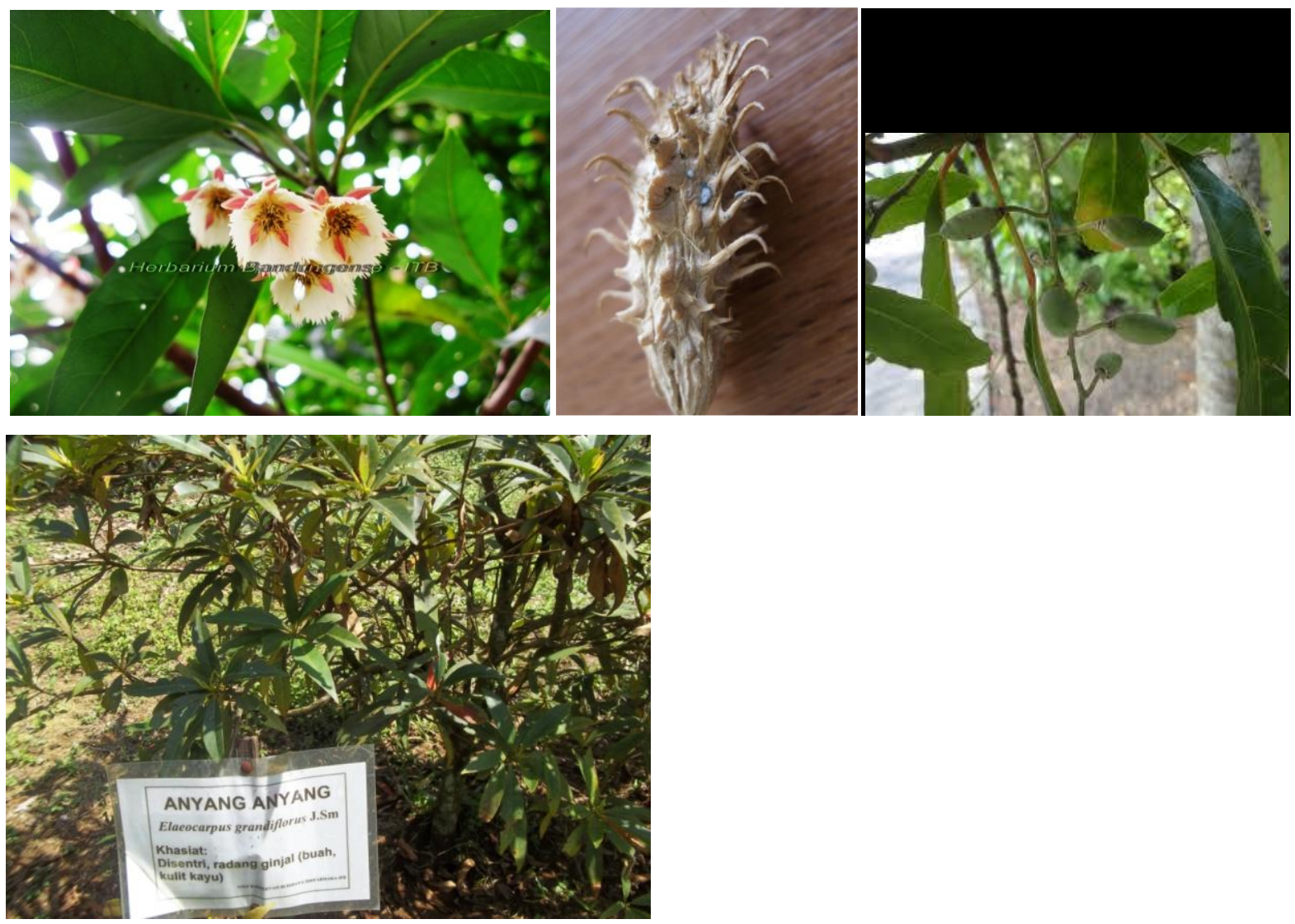

Gambar 1 Tumbuhan Anyang-anyang. Searah jarum jam mulai dari atas: bunga (sumber: Herbarium ITB), biji (sumber: http://www.krbali.lipi.go.id), buah (sumber: http://rumputobat.blogspot.com/2012/04/anyang-anyang.html) dan pohon (sumber: Foto langsung di Kebun Biofarmaka IPB)

Cara menyitat: Sagala, Danner, 2018. "Deskripsi, Metabolit Sekunder Dan Kegunaan Anyang-anyang (elaeocarpus Grandiflorus J.E. Smith)”. INA-Rxiv. February 10. osf.io/preprints/inarxiv/3unv8 
Menurut Sutamto (2010), perbanyakan anyang-anyang dilakukan dengan setek dan biji. Anyang-anyang dirawat dengan disiram air yang cukup, dijaga kelembapan tanahnya, dan dipupuk dengan pupuk dasar. Tumbuhan ini menghendaki tempat yang cukup matahari atau sedikit terlindung.

\section{KANDUNGAN SENYAWA BIOAKTIF DAN LINTASANNYA}

Hampir semua bagian/organ anyang-anyang mengandung senyawa bioaktif. Shah (2011) berhasil mengisolasi tannin, geraniin and 3, 4, 5-trimethoxy geraniin dari daun anyang-anyang. Dalam Warintek (2014) tertulis bahwa daun anyang-anyang mengandung saponin, flavonoid, polifenol dan tannin; buah mengandung saponin, flavonoid, dan tannin; sedangkan kulit batang mengandung saponin, flavonoid,dan polifenol. Sutarno, et al., (1981) menemukan senyawa golongan alkaloid, tannin galat dan sedikit flavonoid dari ekstrak serbuk biji anyang-anyang.

Deteksi senyawa bioaktif atau metabolit sekunder sulit untuk dilakukan karena tergantung pada sensitifitas dari prosedur analitik yang digunakan Vickery dan Vickery, 1981). Oleh karena itu senyawa bioaktif suatu spesies bisa dinamai detil hingga nama terkecil dan bisa juga hanya pada kelompok besar dari senyawa tersebut. Sebagai contoh yang senyawa bioaktif ditemukan pada anyang-anyang yang telah diuraikan di atas. Tannin, geraniin and 3, 4, 5trimethoxy geraniin, Flavonoid dan polifenol merupakan kelompok fenolik, dimana tannin dan flavonoid merupakan polifenol (Croizer et al., 2006) dan geraniin and 3, 4, 5-trimethoxy geraniin merupakan tannin (Luger et al., 1998). Croizer et al., (2006) menyatakan bahwa senyawa fenolik terdiri dari yang sangat sederhana, berat molekul yang rendah, senyawa dengan cincin aromatic tunggal hingga yang tannin yang besar dan komplek dan derivate polifenol. Fenolik juga diklasifikasikan menjadi non flavonoid dan flavanoid. Demikian juga dengan alkaloid yang sesungguhnya di dalamnya termasuk cafein, nikotin dan kokain, namun Sutarno et al., (1981) hanya mampu mendeteksi dan menyebut ada golongan alkaloid dalam anyang-anyang. Oleh karena itu, penulis mengelompokkan senyawa bioaktif yang telah berhasil diisolasi di atas menjadi senyawa terpenoid (saponin), fenolik, dan alkaloid.

Umumnya polifenol memiliki manfaat kesehatan bagi manusia. Namun, sifat defensif sebagian tanin adalah karena toksisitasnya, umum dikaitkan dengan kemampuannya untuk mengikat protein nonspesifik. Senyawa fenolik dapat diperoleh dari lintasa skimat dan lintasan malonat (Taiz dan Zeiger, 2002) dan diuraikan dalam Gambar 2, 3, dan $4 .$.

Saponin berasal dari triterpen tipe dammarane. Saponin ini memiliki sifat seperti sabun sehingga menghasilkan busa pada air. Saponin dapat mengganggu membaran misalnya membrane sel darah merah, sehingga jika berlebihan diinjeksi dapat meracuni manusia. Namun Cara menyitat: Sagala, Danner, 2018. "Deskripsi, Metabolit Sekunder Dan Kegunaan Anyang-anyang (elaeocarpus Grandiflorus J.E. Smith)”. INA-Rxiv. February 10. osf.io/preprints/inarxiv/3unv8 
penggunaan sebagai obat tradisional dengan cara oral tidak menyebabkan keracunan. Salah satu efek terapis saponin adalah anti imflamatori sehingga bisa digunakan untuk obat maag (Croizer et al., 2006). Saponin yag merupakan kelompok terpanoid diperoleh dari lintasan mevalonat (Taiz dan Zeiger, 2002) dan diuraikan dalam Gambar 2 dan 4.

Alkaloid merupakan kelompok senyawa dengan berat molekul yang rendah, umunya berasal dari asam amino dan ditemukan pada $20 \%$ dari seluruh spesies. Sebagai metabolit sekunder, alkaloid telah digunakan sebagai obat-obatan, stimulant, narkotik dan racun (Croizer et al., 2006). Lintasan Alkaloid diuraikan dalam Gambar 4.

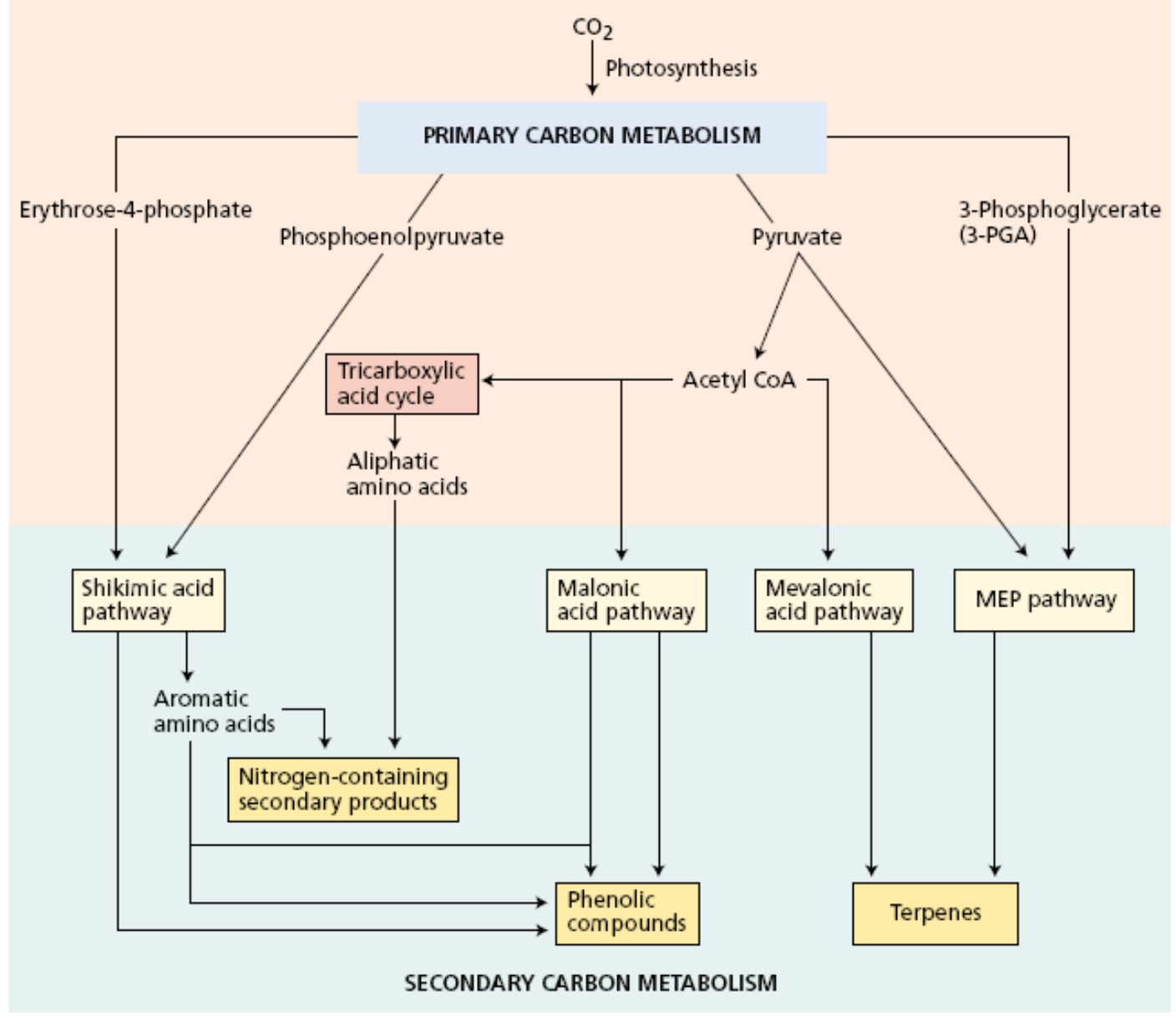

Gambar 2. Hubungan sederhana antara metabolism primer dan metabolism sekunder (Sumber:

Taiz and Zaiger, 2002) 


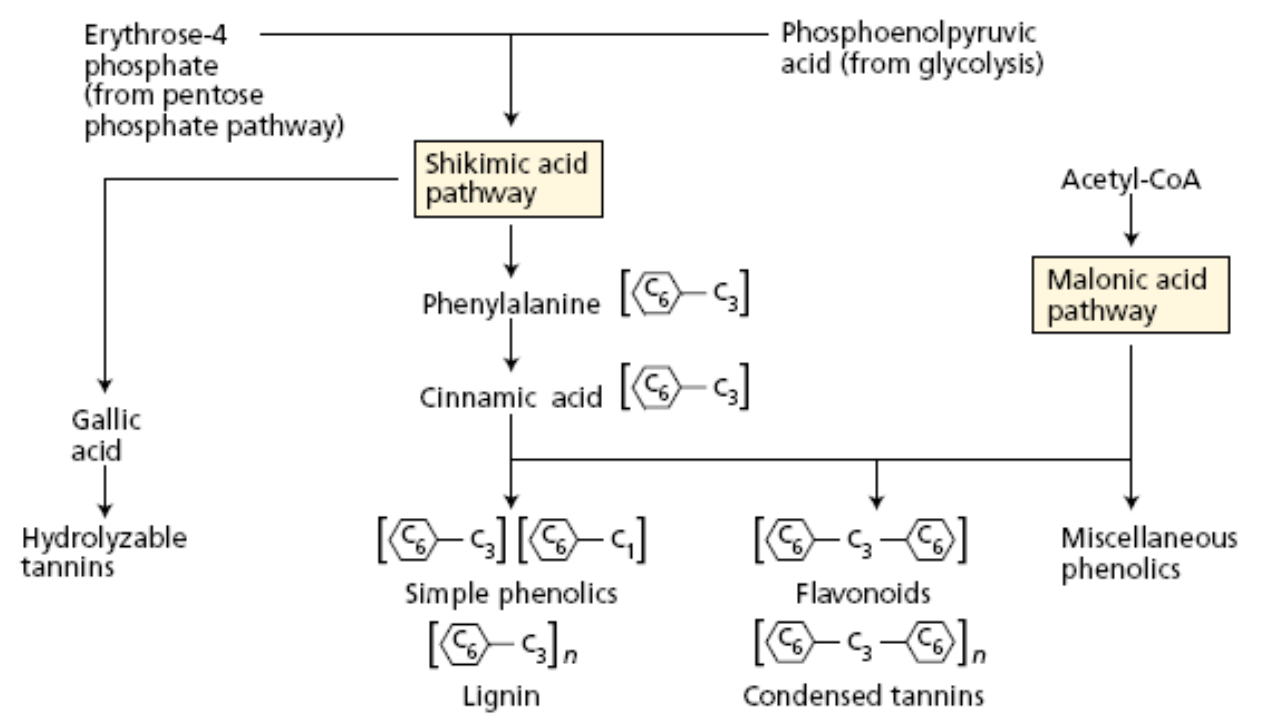

Gambar 3 Penolik tanaman umumnya dibiosintesis dengan beragam cara. Pada tanaman tingkat tinggi, kebanyakan penolik diperoleh dari penilalanin, suatu produk dari lintasan skimat. Formula yang di dalam kurung mengindikasikan susunan rantai karbon dasar (Sumber: Taiz and zaiger, 2002)

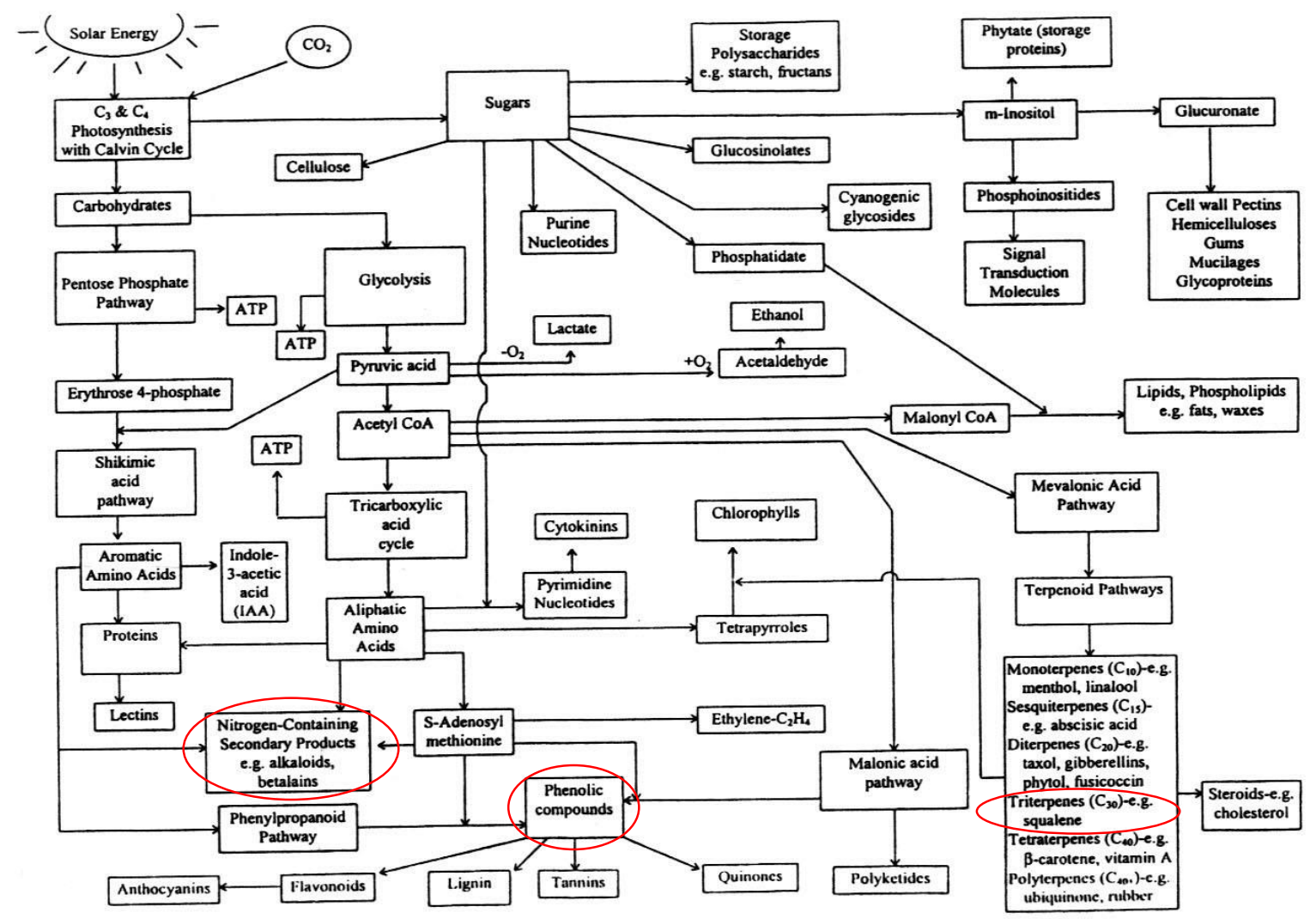

Gambar 4. Skema lengkap metabolit sekunder tanaman

Cara menyitat: Sagala, Danner, 2018. "Deskripsi, Metabolit Sekunder Dan Kegunaan Anyang-anyang (elaeocarpus Grandiflorus J.E. Smith)”. INA-Rxiv. February 10. osf.io/preprints/inarxiv/3unv8 


\section{KEGUNAAN TANAMAN DAN CARA PENYEDIAANNYA}

Dalam farmakologi Cina dan pengobatan tradisional lain disebutkan bahwa tanaman ini memilikki sifat rasa pahit, sejuk, bersifat antipiretik dan anti inflamasi. Penelitian-penelitian di bidang kesehatan menunjukkan bahwa anyang-anyang memiliki kemampuan antibakteri, diuretik (Dachich et al. 2013), dan anti-infektif (Nugraha dan Keller, 2011). Ekstrak air daun, buah dan ranting anyang-anyang telah digunakan secara tradisional untuk mengobati pasien diabetes meskipun tidak ada data ilmiah yang tersedia.

$\mathrm{Xu}$ et al (1996) menguji berbagai tanaman obat tradisional untuk memperoleh kemampuannya dalam menghambat aktifitas HIV-1 protease. Prosentase penghambatan ekstrak buah anyang-anyang terhadap HIV-1 protease adalah 53,8\% (konsentrasi ekstrak 250 $\mu \mathrm{g} / \mathrm{mL}$ ) dan $23 \%$ (konsentrasi ekstrak $25 \mu \mathrm{g} / \mathrm{mL}$ ).

Bualee et al. (2007) menemukan bahwa penggunaan dalam jangka panjang anyanganyang dapat menyebabkan keracunan dalam tubuh. Jangka waktu penggunaan yang paling maksimum adalah dua minggu. Hal ini mungkin terkait dengan kandungan saponin (merusak membrane), tannin (pengerasan, digunakan sebagai penyamak kulit) dan alkaloid (kafein, nikotin dan kokain) yang jika dalam jumlah yang berlebih dapat merugikan.

Berdasarkan literatur bebas (dalam http://eyangresi313.blogspot.com/2010/07/anyanganyang.html) yang mencatat pengalaman secara turun-temurun dari berbagai negara dan daerah, tanaman ini dapat menyembuhkan penyakit-penyakit sebagai berikut:

1. Anyang-anyangen (sakit kandung kemih sehingga kencing tidak lancar). Buah kering 2-5 grm ditumbuk, direbus dan diminum seluruhnya.

2. Borok dan bisul. Daun muda dirumbuk halus, tempelkan kebagian yang sakit.

3. Obat keringat (biang keringat), obat rambut rontok. Daun ditumbuk, peras hingga keluar getahnya, oleskan dibagian yang sakit.

4. Mencret menahun, sakit kepala sebelah. Kulit 250 grm ditambah, ditambah 2 gelas anggur, direbus sampai isinya tinggal separuh, minum.

5. Sariawan. Kulit 250 grm ditambah, ditambah 2 gelas anggur, direbus sampai isinya tinggal separuh, pakai untuk berkumur.

\section{PENUTUP}

Metabolism sekunder tanaman telah banyak diteliti untuk dimanfaatkan dalam berbagai hal. Meskipun sesungguhkan metabolit sekunder ini diproduksi oleh tanaman dengan tujuan tertentu untuk kondisi tertentu bagi keberlangsungan hidup tanaman misalnya pertahanan 
terhadap musuh dan adaptasi terhadap kondisi lingkungan yang tidak baik seperti kekeringan, salinitas tinggi dan lain-lain.

Tanaman anyang-anyang merupakan salah satu dari banyak tanaman yang menghasilkan metabolit sekunder dan berguna bagi manusia. Kandungan metabolit sekunder yang telah berhasil diisolasi terdiri dari kelompok Fenolik, terpenoid dan alkaloid.

\section{DAFTAR PUSTAKA}

[ASEAN] Association of South-East Asian Nation. 2014. ASEAN Tropical Plant Data Base. http://211.114.21.20/tropicalplant/html/search01_view.jsp?rno=733\&fno=\&page=1\&sc ientific $=$ elaeocarpus\&all $=[10$ Maret 2014]

[ITB] Institut Teknologi Bandung. 2014. Herbarium Bandungense Sekolah Ilmu dan Teknologi Hayati. http://www.sith.itb.ac.id/herbarium/index.php?c=herbs\&view=detail \&spid=237332 [8 Maret 2014]

Bualee, C., A. Ounaroon, R. Jeenapongsa. 2007. Antidiabetic and Long-term Effects of Elaeocarpus grandiflorus. http://www.thaiscience.info/Article\%20for\%20ThaiScience/ Article/5/Ts-5\%20antidiabetic\%20and\%20long-term\%20effects\%20of\%20elaeocarpus \%20grandiflorus.pdf [10 Maret 2014]

Crozier, A., M.N. Clifford, H. Ashihara.2006. Plant Secondary Metabolites: Occurrence, Structure and Role in the Human Diet. Blackwell Publishing

Dadhich, A., A.Rishi, G. Sharma. 2013. Phytochemicals of Elaeocarpus With Their Therapeutic Value: A Review. Int j pharm bio sci 2013 july; 4(3): (p) 591 - 598

Luger, P., M. Weber, S. Kashino, Y. Amakura, T Yoshida, T Okuda, G. Beurskensd, B. Dautere. 1998. Structure of the Tannin Geraniin Based on Conventional X-ray Data at

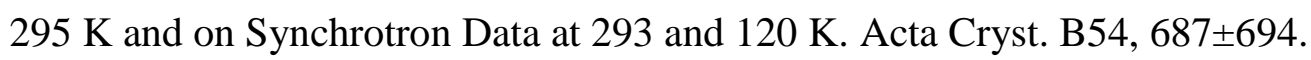

Nugraha, A. S. and Keller, P. A. (2011). Revealing indigenous Indonesian traditional medicine: anti-infective agents. Natural Product Communications, 6 (12), 1953-1966.

Rahmawati, S. 2014. SENYAWA METABOLIT SEKUNDER. https://www.academia.edu/ 5330992/SENYAWA_METABOLIT_SEKUNDER_A [8 Maret 2014]

Shah, G., P.S. Singh, A.S.Mann, R.Shri. 2011. Scientific Basis for The Chemical Constituent And Therapeuticuse Of Elaeocarpus Species: A Review. International Journal of Institutional Pharmacy and Life Sciences 1(1): July-August 2011

Sutamto. 2010. Tanaman Obat Keluarga. http://flora-sutamto.blogspot.com/2010/03/anyanganyang.html [9 Maret 2014]

Taiz, L. dan E. Zeiger. 2002. Plant Physiology. Sinauer Associates

Cara menyitat: Sagala, Danner, 2018. "Deskripsi, Metabolit Sekunder Dan Kegunaan Anyang-anyang (elaeocarpus Grandiflorus J.E. Smith)”. INA-Rxiv. February 10. osf.io/preprints/inarxiv/3unv8 
Vickery, M.L. dan B. Vickery. 1981. Secondary Plant Metabolism. The Mac Milan Press.

[WARINTEK] Warung infornasi Teknologi Kementerian Riset dan Teknologi. 2014. Elaeocarpus grandiflorus J.E. Smith. http://www.warintek.ristek.go.id/ pangan_kesehatan/tanaman_obat/depkes/3-011.pdf [20 Maret 2014].

Xu, H., M. Wan, B. Loh, O. Kon, P. Chow dan K. Sim. Screening of Traditional Medicines for their Inhibitory Activity Against HIV-1 Protease. PHYTOTHERAPY RESEARCH, VOL. 10,207-210 (1996) 